\title{
THE EFFECT OF CASH HOLDING POLICY, DIVIDEND POLICY, AND PROFITABILITY ON STOCK PRICES
}

\author{
Adisa Humaira, Hendro Susanto \\ Universitas Ciputra Surabaya
}

\begin{abstract}
Increased non-resident ownership makes the capital market vulnerable to declining stability and the global economy that can affect the condition of the financial sector as indicated. These factors will affect the company's stock price is the company's cash holding policy, dividend policy and profitability performance. This study aims to determine the effect of cash holding policy, dividend policy and profitability on the company's stock price. Cash holding policy variables are measured by a cash to asset ratio, dividend policy is measured by a dividend pay-out ratio, profitability is measured by return on equity (ROE) and stock prices are measured by a price to book ratio. This research is a quantitative study using multiple regression analysis methods. The data used are secondary data from the annual report and the stock market performance reports of financial sector companies listed on the Indonesia Stock Exchange. The sampling method uses purposive sampling with an observation period of 2011-2017 and there are 14 companies that meet the criteria. The results showed that cash holding and profitability policies had a significant effect on stock prices dividend policy had no significant effect on stock prices.
\end{abstract}

Keywords: cash holding, dividend policy, profitability, stock price

\section{INTRODUCTION}

The development of the capital market has a very big influence on a country's economy. The capital market has a function which is to become a place for funding. Funding in the capital market carries the risk of uncertainty from fluctuations in income that will be received as returns. According to the chairman of the Board of Commissioners of Financial Services Authority Wimboh Santoso, the capital market is one of the keys in Indonesia's economic development

\footnotetext{
*Corresponding Author.

e-mail: ahumaira@student.ciputra.ac.id
} 
(Wulandari \& Yolanda, 2019). Fundraising in the capital market over the past five years has increased. This is indicated by the increasing number of listed companies and the number of investors in the Indonesia Stock Exchange (Tari, 2019).

The capital market in Indonesia experienced an increase in non-resident ownership as shown in Figure 1. In 2011 to 2012 there was an increase of 7.47\%. In 2012 to 2013 there was a decrease of $0.51 \%$. In 2013 to 2014 there was a decrease of $7.43 \%$. In 2014 to 2015 there was an increase of $7.3 \%$. In 2015 to 2016 there was an increase of $12.59 \%$. in 2016 to 2017 there was a decrease of $3.19 \%$. The increase in ownership shows that the stock market is increasingly dominated by foreign investors. Despite the decline, it still shows that the Indonesian stock market is dominated by foreign investors. The increase in non-resident ownership shows the high interest of foreign investors to conduct funding in the Indonesian capital market. However, a significant increase will make the Indonesian economy and financial stability more vulnerable to uncertainty and global economic turmoil (Bank Indonesia, 2018).

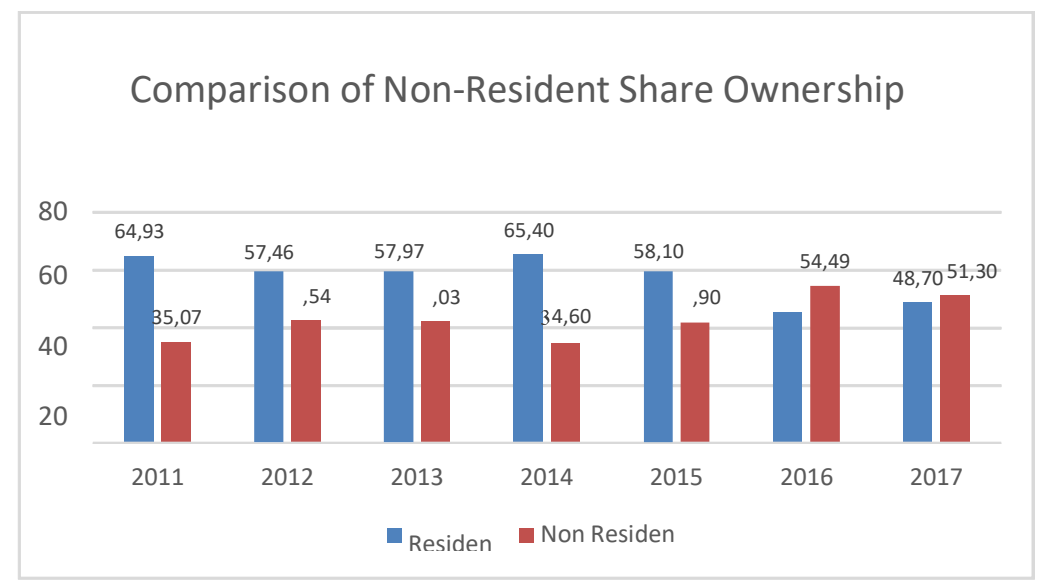

Figure 1 Comparison of Non-Resident Share Ownership 2011-2017

Based on previous research that examined the effect of cash holding policies on stock prices by Sutrisno (2017) shows that cash holding policies has effect on stock prices. The higher the cash held on cash flow report, the price of the company's shares will increase. However, research by Darko et al. (2018) shows 
that cash holding does not affect the value of the company, because cash holding in companies not use to carry out activities that will add value to the company. Previous research examining the effect of dividend policy on stock prices by Ganar (2018) shows that dividend policy has effects on stock prices, the higher the DPR will raise the company's share price. However, research by Dereli \& Topak (2018) shows that dividend policy has no effect on stock prices. Even though the dividend policy has increased, this is not the main indicator for finance performance evaluation. Previous research that examined the effect of profitability ratios on stock prices by Agustami \& Arifin (2016) showed profitability ratios (ROE) has affected on stock prices, profitability being an indicator seen by investors in managing capital invested by investors.

The inconsistency on past studies attract the researcher to re-examine to find out whether cash holding policy, dividend policy and profitability, affect the stock price of finance companies in Indonesia. This reason has led the researchers to conduct a study entitled "The Effect of Cash Holding Policy, Dividend Policy, Profitability on Stock Prices"

The hypotheses are as follow:

H1: Cash holding policy affects the stock price.

.H2: Dividend policy affects the stock price.

H3: Profitability affects the stock price.

\section{METHOD}

\section{Population and Sample}

The research population includes all finance companies in Indonesia. The sampling technique is purposive sampling method. The criteria used in this study include:

1. The finance companies are consecutively listed on the IDX in the 2011-2017 period.

2. The finance companies are consecutively announced dividend in the 20112017 period.

3. The companies always published their financial reports and annual reports in the 2011-2017 period on the IDX website or the company's official website.

4. The companies' financial statements show profits. 
The population in this study were 90 financial sector companies listed on the Indonesia Stock Exchange (IDX). The sample of this study took all finance companies listed on the Indonesia Stock Exchange which resulted in 14 companies or 98 data observation.

Data collection is completed using the documentation technique. The data used and collected in this study is the secondary data. Secondary data used are mainly the annual reports financial reports and stock price reports issued by finances companies on the official IDX website and/ or the official website of each company that can be downloaded.

\section{Operational Definition and Variable Measurement Independent Variable of Cash Holding Policy}

The cash holding policy is an important activity for companies, if the operational activities had a high risk. The cash held must have a balance so that financial. If the cash is too large, it causes unexpected costs to come out. Financial managers can hold cash and cash equivalents for operational or investment activities. Companies that hold cash and cash equivalents can carry out investment activities in the future is an indication that the company has a large investment opportunity (Suherman, 2017). A good cash holding policy, if it is constantly increasing (Sutrisno, 2017). Cash holding variable will be measured by cash to asset ratio

$$
\text { CASH }: \frac{\text { Cash }+ \text { Cash Equivalent }}{\text { Total Asset }} \times 100 \%
$$

\section{Independent Variable of Dividend Policy}

Dividend policies announced by companies can provide information to the public about the condition of the company. If the dividends given increase optimally, it shows that the company's condition good and the level of investment transactions to the company will rise. Dividend policy will be adjusted to the condition of the company. An optimal dividend policy is demonstrated by a balance between current dividend policy and future dividend policy that can 
maximize stock prices (Brigham \& Weston, 2005). Dividend policy variable will be measured by dividend pay-out ratio.

$$
\frac{\text { Divident per Share }}{\text { Earning per Share }} \times 100 \%
$$

\section{Independent Variable of Profitability (ROE)}

Profitability ratio is the ratio that will show the company's performance in generating profits by managing company assets or equity. The profitability ratio is the main company performance indicators for investors, because investors who put capital into the company will know the managing of equity in the companies. (Ganar, 2018; Agustami \& Arifin, 2016).

Profitability variable will be measured by return on equity ratio.

$$
\frac{\text { Net Income }}{\text { Total Equity }} \times 100 \%
$$

\section{Dependent Variable of Stock Price}

Stocks are financial products that are traded on a country's capital market. To conduct a stock trading transaction, a share price is issued that shows the price per share issued by the company. The stock price will be the first thing that will be seen by investors before making a transaction in a related company. Then the higher the company's stock price the investor will invest in investment. However, stock prices can be influenced by several fundamental factors that will occur stock price fluctuations (Egam et al., 2017). Stock price variable will be measured by price to book value ratio.

$$
\frac{\text { Price per Share }}{\text { Book Value per Share }} \times 100 \%
$$

\section{Data Analysis Method}

The following test as the method: Descriptive Statistics, Classical Assumption Test Multiple Linear Regression Analysis. Goodness of Fit Model Test and Hypothesis test. 
Journal of Accounting, Entrepreneurship, and Financial Technology

Volume 01, Number 02, April 2020

\section{RESULTS}

The object of this research is the finance companies listed on the Indonesia Stock Exchange in 2011-2017. in this study showed the existence of abnormal data, the researchers conducted an outlier test to eliminate 35 data. The data processed in SPSS were 63 sample data.

\section{Descriptive Statistic of Research Variables}

Based on table 1 shows the minimum CASH value of 0.01 that is owned by the insurance sub-sector company which means that the company holds the least amount of cash and cannot fully bear the risk of unexpected costs, but the subsector company can carry out a strategy to hold cash enough so that there is no opportunity cost. The maximum value of CASH 0.36 owned by BNBA is the banking subsector company. Showing that the company is holding high cash holdings to reduce the risk of unexpected costs from operational activities, the banking subsector company will hold higher cash holdings compared to other subsectors. The average value (mean) of financial sector companies in 2011-2017 is 0.1178 and the standard deviation value is 0.08999 . Showing that the standard deviation is smaller than the average value, then the CASH data do not deviate.

Table 1 Result of Statistics Descriptive

\begin{tabular}{llcccc}
\hline Variabel & $\mathbf{N}$ & Minimum & Maximum & Mean & Std. Deviation \\
\hline CASH & 63 & 0.01 & 0.36 & 0.1178 & 0.08999 \\
DIVIDEN & 63 & 0.16 & 0.45 & 0.2890 & 0.06334 \\
ROE & 63 & 5.83 & 31.22 & 17.7000 & 6.32019 \\
SAHAM & 63 & 0.36 & 2.64 & 1.2940 & 0.57081 \\
\hline
\end{tabular}

Based on Table 1 shows the minimum value of 0.16 DIVIDENDS owned by BMRI which shows that in that year BMRI issued the smallest dividend in all samples of this study. This information will be received negatively by investors. The maximum value of 0.45 is owned by BMRI which shows that the banking company does not provide a stable dividend. The average value (mean) of financial sector companies in 2011-2017 is 0.2890 and the standard deviation value is 0,06334 indicating that the standard deviation value is smaller than the average value, then the DIVIDEND data do not deviate. 
Based on Table 1 shows the minimum value of ROE owned by TIFA of 5.83 which shows that the company's performance in managing equity to get profit is not going well. This information will be interpreted negatively by investors and may affect the company's stock price. The maximum value of 31.22 is owned by BBRI which shows that the banking sub-sector has a higher ROE, so that in the banking sub-sector has a high level of capital and profits generated from capital management. The average value (mean) of financial sector companies in 20112017 is 17.70000 and the standard deviation value is 6.32019 Shows that the standard deviation value is smaller than the average value, then the ROE data does not deviate.

Based on Table 1 shows the minimum value of SHARE 0.36 owned by BNBA, it shows that the value of the company's shares is declining. The maximum value of 2.64 owned by BBNI, then shows the value of the highest company shares and the company is in good condition for investors. The average value (mean) of financial sector companies in 2011-2017 is 1.2940 and the standard deviation value is 0,57081 indicating that the standard deviation value is smaller than the average value, then the STOCK data does not deviate.

\section{Classic Assumption Test}

There's four classic assumption test that must be tested: normality test, multicollinearity test, heteroskedastic test and autocorrelation test. In this study, all the test had been pass with significant above $>0.05$.

Table 2 Result of Normality Test

\begin{tabular}{cc}
\hline & Asym. Sig. (2-tailed) \\
\hline Unstandardized Residual & 0.998 \\
\hline
\end{tabular}

Table 3 Result of Multicollinearity Test

\begin{tabular}{lcc}
\hline \multicolumn{1}{c}{ Model } & Tolerance & VIF \\
\hline CASH & 0.730 & 1.370 \\
DIVIDEN & 0.728 & 1.374 \\
ROE & 0.987 & 1.014 \\
\hline
\end{tabular}


Table 4 Result of Heteroskedastic Test

\begin{tabular}{lc}
\hline \multicolumn{1}{c}{ Sperman Rho } & Unstandarized Residual \\
\hline Correlation Coefficient & 1.000 \\
CASH & 0.130 \\
DIVIDEN & 0.091 \\
ROE & 0.905 \\
\hline
\end{tabular}

Table 5 Result of Autocorrelation Test

\begin{tabular}{cc}
\hline Run Test & UnstandardizedResidual \\
\hline Asymp.Sig(2-tailed) & 0.099 \\
\hline
\end{tabular}

\section{Multiple Regression Analysis Test}

Constanta in the research regression model amounted to -0.257 , indicating that the stock price data has decreased. The Beta coefficient on the cash holding policy (X1) is 1,458 . The results of the cash holding policy coefficient show, if the cash holding has increased the share price will increase. The Beta coefficient on the dividend policy (X2) is 0.987. The results of the dividend policy coefficient show, if the dividend policy increases, the stock price will increase. Beta coefficient on the profitability ratio (X3) of 0.062 . The results of the profitability ratio coefficient indicate, profitability has increased, the stock price will increase.

$$
\mathrm{Y}=-0.257+1.458 \mathrm{X} 1+0.987 \mathrm{X} 2+0.062 \mathrm{X} 3+0.387
$$

\section{Goodness Fit of Model Test F Statistic Test}

In the Table 6, it shows that the $\mathrm{F}$ test results for the research hypotheses have a significance value of $0,000<0.05$. The regression model in this study will pass the model feasibility test and can be continued to conduct hypothesis testing.

Table 6 Result of F- Statistics Test

\begin{tabular}{ccc}
\hline Model & F & Sig \\
\hline Regression & 18.386 & 0.000 \\
\hline
\end{tabular}




\section{Adjusted R Square}

In Table 7 , it shows that the adjusted $\mathrm{R}^{2}$ test results of 0.457 , it can be concluded that the cash holding policy (X1), dividend policy (X2) and profitability ratio $(\mathrm{X} 3)$ can explain the variable stock price $(\mathrm{Y})$ of $45.7 \%$, the remaining $54.3 \%$ is owned by other variables that are not in the regression model.

Table 7 Result of Adjusted R Square Test

\begin{tabular}{cc}
\hline Model & Adjusted R Square \\
\hline 1 & 0.457 \\
\hline
\end{tabular}

Hypothesis Testing

Table 8 Result of $\mathrm{t}$-Test

\begin{tabular}{|c|c|c|c|c|c|}
\hline \multirow{2}{*}{ Model } & \multicolumn{2}{|c|}{$\begin{array}{l}\text { Unstandardized } \\
\text { Coefficients }\end{array}$} & \multirow{2}{*}{$\begin{array}{c}\text { Standardized } \\
\text { Coefficients }\end{array}$} & \multirow{2}{*}{$\mathrm{T}$} & \multirow{2}{*}{ sig } \\
\hline & B & Std.Error & & & \\
\hline Constant & -0.257 & 0.387 & & -0.666 & 0.508 \\
\hline CASH & 1.458 & 0.695 & 0.230 & 2.098 & 0.040 \\
\hline DIVIDEN & 0.987 & 0.989 & 0.110 & 0.999 & 0.322 \\
\hline ROE & 0.062 & 0.009 & 0.685 & 7.265 & 0.000 \\
\hline
\end{tabular}

In Table 8, shows that the results of the $t$ test for the research hypothesis: for the $\mathrm{H} 1$ research hypothesis for the cash holding variable (CASH) the significance value is $0.040<0.05$. Then it can be concluded that cash holding (X1) has a significant effect partially on stock prices (Y) and H1 is accepted. for the $\mathrm{H} 2$ research hypothesis for the dividend policy variable (DIVIDEND) the significance value is $0.322>0.05$. Then it can be concluded that the dividend policy (X2) has no significant effect partially on stock prices (Y) and H2 is rejected. for the $\mathrm{H} 3$ research hypothesis for the profitability ratio (ROE) variable the significance value is $0.000<0.05$. Then it can be concluded that the profitability ratio $(\mathrm{X} 3)$ has a partially significant effect on stock prices $(\mathrm{Y})$ and $\mathrm{H} 3$ is accepted. 


\section{DISCUSSION}

\section{The Effect of Cash Holding Policy towards The Stock Price}

Hypothesis test results show that cash holding has a significant effect on stock prices, it can be concluded that the research hypothesis 1 is accepted. This shows that companies that carry out cash holding policies can affect the company's stock price.

The results of the sample characteristics passed the descriptive statistical test showing that with a minimum value of 0.01 and a maximum of 0.36 for the financial sector companies. The insurance sub-sector showed a tendency to hold smaller cash holdings and the company's stock price was shown to be small compared to other sectors. The maximum value held by the subsector of banks with the level of risk in the company's operational activities. The study show in financial sector companies have implemented a cash holding policy in a constant and stable manner. However, companies must think about cash management that does not create opportunity costs that will add to costs that are not needed by the company.

The results of this study are in line with Putra \& Rahmawati (2016) which shows that the cash holding policy is significant and positively influences the value of the company, if the company carries out cash holding it will facilitate the company in making future investments and reducing unnecessary external costs. if the company does not have sufficient free funds it will cause a large risk to the company to finance unexpected costs. The results of this study are in line with Sutrisno (2017) which shows that cash holding has a positive effect on firm value. The higher the cash and cash equivalents held by the company, the value of the company will rise.

\section{The Effect of Dividend Policy towards the Stock Price}

Hypothesis test results show that dividend policy does not have a significant effect on stock prices, it can be concluded that the research hypothesis (H2) is rejected. This shows that companies that announce and/or pay dividends do not affect the company's stock price.

The results of the sample characteristics through descriptive statistical tests show the minimum value of 0.16 and the maximum value of 0.45 owned by BMRI. 
It shows that the banking sub-sector is experiencing a decline in performance. This is an indication that the dividend policy at the company is unstable.

The results of this study are in line with Dereli \& Topak (2018) which shows that dividend policy has no effect on stock prices, if the company provides cash dividends the company's stock prices will not increase. This shows that even though cash dividends are announced and paid does not increase the desire and confidence of investors in buying shares. The results of this study are in line with Anita \& Yulianto, (2016) which shows that dividend policy has no effect on stock prices, if the company provides cash dividends the company's stock prices will not increase. Investors are more concerned with long-term profits such as capital gains than cash dividends distributed during that period. Capital gains can meet the long- term needs of investors which is one of the major considerations in generating profits.

\section{The Effect of Profitability towards the Stock Price}

Hypothesis test results indicate that profitability with ROE indicators significantly influence stock prices, it can be concluded that the research hypothesis (H3) is accepted. This shows that companies that have high ROE values can affect the company's stock price.

The results of the sample characteristics through descriptive statistical tests show a minimum value of 5.83 and a maximum value of 31.22 owned by the banking subsector. In the case of TIFA, the company experienced a decline in performance that year. In BBNI companies that have a maximum value showing efficiency in managing capital to generate profits, the company's stock price in that year is shown to have experienced a rapid increase.

The results of this study are in line with Agustami \& Arifin (2016) show that the profitability ratio with the indicator of return on equity (ROE) has a significantly positive effect on stock prices. stock prices and profitability (ROE) have risen at the same time then stock prices will experience fluctuations.

\section{Conclusion}

Cash holding policy has a significant effect on the stock prices of finance companies in 2011 to 2017 . The higher the holding of cash and cash equivalents 
compared to the total assets of the company and stock price will increase. Cash holding policy shows the level of desire to eliminate risk in operational activities and carry out investment activities in the future to add value to the company. Dividend policy does not significantly influence the stock prices of finance companies in 2011 to 2017 . The higher the dividend payment, the stock price does not increase or decrease, because dividend policy is not the main concern of investors in seeking profits in the stock market. Profitability has a significant effect on the stock prices of finance companies in 2011 to 2017. The higher the announced profitability, the stock price will increase. Profitability shows the company's performance in generating profits by managing equity.

\section{Implication}

The implication of this research for companies is that companies must hold cash holdings in accordance with each company size and its subsector because they have different operational activities and the level of risk in carrying out their activities. Companies that have a cash holding policy must experience a steady and optimal increase so that investors can assess properly. The use of the cash must be utilized to carry out activities that add value.

The activity of developing efficient customer service using machines or applications to facilitate customers in conducting transactions. Funding activities such as business expansion to grow the company. these activities can increase profits and company performance which will increase investor confidence and interest. The results of this study can add new considerations to companies to prioritize long-term investment returns. This needs to be done by the company because of a short-term result such as dividends. Capital gain is one of the activities that can be applied to the company. Stock price differences cannot be calculated instantly but generate greater profits.

\section{REFERENCES}

Agustami, S. \& Arifin, N. F. (2016). Pengaruh Likuiditas, Solvabilitas, Profitabilitas, Rasio Pasar, dan Ukuran Perusahaan terhadap Harga Saham (Studi Pada Perusahaan Subsektor Perkebunan yang Terdaftar di Bursa Efek Indonesia 
Adisa Humaira, Hendro Susanto / The Effect of Cash Holding Policy, Dividend Policy, and Prifitability on Stock Prices

Tahun 2010-2014). Jurnal Riset Akuntansi dan Keuangan, 4(3), 11891210.

Anita, A. \& Yulianto, Ar. (2016). Pengaruh Kepemilikan Manajerial dan Kebijakan Dividen Terhadap Nilai Perusahaan. Management Analysis Journal, 5(1), 17-23.

Bank Indonesia. (2018). IDX Kajian Stabilitas Keuangan Maret 2018. Jakarta: Bank Indonesia Departemen Kebijakan Makroprudensial, 1-260.

Brigham, E. F. \& Weston, J. F. (2005). Dasar-Dasar Manajemen Keuangan, Edisi Kesembilan, Jilid 2. Jakarta: Penerbit Erlangga.

Darko., Disraeli A., Bonsu, Bright A., Famiyeh., Samuel, Kwartang, Amoako, \& Goka, Yaya. (2018). Governance Structures, Cash holdings and Firm Value on The Ghana Stock Exchange. The International Journal of Business in Society, 18(4), 1-16

Dereli, H. \& Topak, M. S. (2018). The Effect of Dividend Policy on Stock Price: Evidence from an Emerging Country. Journal of Business Research-Turk, 10(4), 1186-1197.

Tari, D. N. (2019). 5 Tahun Jokowi-JK, Pasar Saham Kian Semarak, https:// market.bisnis.com/read/20191015/7/1159215/5-tahun-jokowi-jk-pasarsaham- kian-semarak.

Egam, Gerald E. Y., Ilat, V., \& Pangerapan, S. (2018). Pengaruh Return on Asset (ROA), Return on Equity (ROE), Net Profit Margin (NPM), dan Earning Per Share terhadap Harga Saham Perusahaan yang Tergabung Indeks LQ45 di Bursa Efek Indonesia Periode Tahun 2013-2015. Jurnal EMBA, 5(1), 105-114.

Ganar. (2018). Pengaruh Kebijakan Dividen dan Profitabilitas Terhadap Nilai Perusahaan pada Perusahaan pada Perusahaan yang Terdaftar di Bursa Efek Indonesia Periode 2013-2017. Jurnal Sekuritas, 2(1), 32-44.

Putra, A. R. \& Rahmawati, S. (2016). Pengaruh Mekanisme Corporate Governance dan Cash Holding terhadap Nilai Perusahaan Manufaktur di Indonesia, Jurnal Ilmiah Mahasiswa Ekonomi Manajemen, 1(1), 92-109.

Suherman. (2017), Faktor-Faktor yang Memengaruhi Cash Holdings Perusahaan di Bursa Efek Indonesia. Jurnal Manajemen, 21(3), 36-349.

Sutrisno, B. (2017). Hubungan Cash Holding dan Nilai Perusahaan di Indonesia, Jurnal Dinamika Akuntansi dan Bisnis, 4(1), 45-56. 
Journal of Accounting, Entrepreneurship, and Financial Technology

Volume 01, Number 02, April 2020

Wulandari, R. \& Yolanda, F. (2019). OJK: Modal Bisa Topang Pertumbuhan Ekonomi Nasional. https://republika.co.id/berita/pw3z61370/ojk-pasar-modalbisa-topang- pertumbuhan-ekonomi-nasional. 